\title{
Molecular Characterization of Van Genes Found in Vancomycin-Resistant Enterococcus spp. Isolated from Hospital das Clínicas, FMUSP, São Paulo, Brazil
}

\author{
Caiaffa Filho H.H., Almeida G.D.,Oliveira G.A., \\ Sarahyba L., Mamizuka E.M. and Burattini M.N.
}

\begin{abstract}
Laboratory of Medical Investigation LIM 03, Pathology Department of Medical School of University of São Paulo; Pathological Sciences Department of Medical Sciences Faculty of Santa Casa de São Paulo; Faculty of Pharmaceuthical Sciences of University of São Paulo, São Paulo, SP, Brazil
\end{abstract}

\begin{abstract}
Vancomycin-resistant enterococci strains (VRE) is an important pathogen related with hospital infections in many countries, presenting limited or no therapeutic options for treating serious infections. VRE has presented some different genotypes been $\operatorname{Van} \mathrm{A}$ and $\operatorname{Van} \mathrm{B}$ considered to be the most important in hospital environments. In the present study the authors investigated the prevalence of van genes $(A, B$ an $C)$ among clinical isolates of VRE in a five month period at a large tertiary hospital in Sao Paulo, Brazil. The results showed the presence of van $\mathrm{A}$, but not van $\mathrm{B}$ or van $\mathrm{C}$ in all 43 strains of $E$. faecalis and five $E$. faecium studied. The results bring an important issue, due to the possibility of resistance spread of vanA genes, to be monitored and solved by the hospital infection control team and the microbiology and molecular biology laboratories at tertiary Hospitals.

Key Words: Enterococci, vancomycin resistance, hospital infections.
\end{abstract}

Enterococcus spp. are part of the normal gastrointestinal flora, together with close to 100 other species of aerobic and anaerobic bacteria [1]. Initially, the enterococci were considered to be only slightly virulent, however the rapid emergence and dissemination of vancomycin-resistant enterococci strains (VRE) has completely changed the clinical relevance of these pathogens. Presently, VRE are an important cause of hospital infections in many countries, with limited or no therapeutic options for treating serious infections [2,3]. There is concern that resistance genes in VRE might be transferred to other gram-positive microorganisms, making the situation even worse. In addition, VRE has caused outbreaks and became

Received on 22 April 2002; revised 10 May 2002.

Address for correspondence: Dr. Hélio H. Caiaffa Filho. Rua Santelmo, 121,Zip code: 04031-000, São Paulo/SP, Brazil. Phone (55 11)3069-7174. Fax: (55 11)3083-2498.

E-mail: hcaiaffa@hcnet.usp.br

The Brazilian Journal of Infectious Diseases 2003;7(3):173-174 (C) 2003 by The Brazilian Journal of Infectious Diseases and Contexto Publishing. All rights reserved. endemic in several hospitals, presenting a challenge for hospital infection control teams [2-4]

Till now, six different genotypes of VRE have been found (Van A, B, C, D, E and G) [3,5,6]. VanA and Van $\mathrm{B}$ vancomycin resistance determinants are considered to be the most important, due to conjugative transfer, which may occur via plasmids or transposons. Also, glycopeptide resistance could be passed on to other pathogens, such as methicillin-resistant Staphylococcus aureus, transforming them into highly dangerous, difficult to treat, pathogens [2,3,7].

We investigated the prevalence of van genes among clinical VRE strains found during a 5 month period at the Hospital das Clínicas da Faculdade de Medicina da Universidade de São Paulo (HCFMUSP). The samples were isolated from 48 different patients between May and September 1999, 12 of which were from surveillance cultures and 36 from patients. Five strains were identified as Enterococcus faecium and 43 as Enterococcus faecalis.

The oligonucleotide primers directed towards vanA, $v a n \mathrm{~B}$ and van $\mathrm{C}$ genes in enterococci and the 
Polymerase Chain Reaction (PCR) techniques used were as described by CDC's Antimicrobial Resistance Working Team [8-11].

All the strains presented the van $\mathrm{A}$ gene and produced the expected $1030 \mathrm{bp}$ amplicon with $v a n A$ primers. None of the strains with the vanA gene gave positive PCR results with van $\mathrm{B}$ or van $\mathrm{C}$ primers.

In Brazil, the first vancomycin-resistant Enterococus faecium was isolated in Curitiba, Parana in 1996. Subsequently, numerous isolates of VRE have been made throughout Brazil. However, only some of these have been reported in the literature [12-16].

As all the strains in our study presented the van $\mathrm{A}$ gene, there is a potentially high risk that they could spread to other hospitals (13Woodford, 1998; French, 1998; 2Centinkaya et al., 2000). Consequently, infection control measures to prevent the spread of VRE have been implanted. The HCFMUSP is a large, complex, tertiary hospital with 1500 beds that attends seriously ill patients at high risk for hospital infections. This fact increases the probability of the dissemination of VRE. Additionally, as enterococci are enteric bacteria and the intestinal lumen offers a favorable environment for bacterial conjugation, the vanA gene could be disseminated to other enterococci species and to other bacteria genera. This is an important issue that needs to be monitored and resolved by the hospital infection control team and by microbiology and molecular biology clinical laboratories. Additional studies are in progress to help determine the impact of VRE and its patterns of transmission in our hospital.

\section{References}

1. Mitsuoka T. A Profile of Intestinal Bacteria. Yakult Honsha Co., Tokyo, 1990, p.176.

2. Woodford N. Glycopeptide-resistant enterococci: a decade of experience. J Med Microbiol 1998;47:849-62.

3. Cetinkaya Y., Falk P., Mayhall C.G.. Vancomycin-resistance Enterococci. 2000;13(4):686-707.

4. Noble W.C., Virani Z., Cree R.G.A. Co-transfer of vancomycin and other resistance genes from Enterococcus faecium NCTC 12201 to Staphylococcus aureus. FEMS Newsl. 1992;93:195-8.
5. Mckessar S.J., Berry A.M., Bell J.M., et al. Genetic characterization of van $G$, a novel vancomycin resistance locus of Enterococcus faecalis. Antimicrob. Agents Chemother 2000;44(11):3224-8.

6. Fines M., Perichon B., Reynolds P., et al. Van E, a new type of acquired glycopeptide resistance in Enterococcus faecalis BM4405. Antimicrob. Agents Chemother 1999;43(9):2161-4.

7. Gambarotto K., Ploy M.C., Turlure P., et al. Prevalence of Vancomycin-Resistance Enterococci en Fecal Samples from Hospitalized Patients an Nonhospitalized Controls in a Cattle-Rearing Area of France. 2000;38(2):620-4.

8. Clark N.C., Cooksey R.C., Hill B.C., et al. Characterization of glycopeptide-resistant Enterococci form U.S. hospitals. Antimicrobial Agents Chemother 1993;37:2311-7.

9. Satake S., Clark N., Rimland D., et al. Detection of vancomycin-resistant Enterococci in fecal samples by PCR. J Clin Microbiol 1997;35:2325-30.

10. Clark N.C., Teixeira L.M., Facklam R.R., Tenover F.C. Detection and Differentiation of vanC-1, vanC-2, and vanC-3 Glycopeptide Resistance Genes in Enterococci. 1998;36(8):2294-7.

11. Tenover F.C., Lancaster M.V., Hill B.C., et al. Characterization of staphylococci with reduced susceptibilities to vancomycin and other glycopeptides. J Clin Microbiol 1998;36:1020-7.

12. Cereda R.F., Pignatari A.C., Leme I.L., et al. Avaliação da sensibilidade in vitro de 446 amostras clínicas de bactérias gram-positivas testadas para novos antimicrobacterianos da classe das quinolonas, carbapenens e cefalosporinas. 1996;42(2):130-4.

13. Zanella R.C., Darini A.L.C., Brandileone M.C.C., et al. Análise molecular de Enterococcus e dos seus elementos van A que medeiam resistência à vancomicina, isolados na Casa de Saúde Santa Marcelina -SP, em 1998. Braz J Infect Dis 1999;3(suppl 2): S07.

14. Zanella R.C., Valderato F., Lovgren M., et al. First confirmed case of a vancomycin-resistant Enterococcus faecium with VanA phenotype from Brazil: isolation from a meningitis case in São Paulo. Microb Drug Resist 1999;5(2):159-62.

15. D’Azevedo P.A., Kacman S.B., Achmalfuss T., et al. Primeiro caso de Enterococcus resistente à vancomicina isolado em Porto Alegre, RS. J Bras Patol 2000;36(suppl 3):258.

16. Menezes-Silva C.R., Hayashi M.M., Ribas R.M., GontijoFilho P.P. Pesquisa de Enterococcus resistentes aos glicopeptídeos em humanos, aves e ambiente, na cidade de Uberlândia, MG. XX Congresso Brasileiro de Microbiologia, Salvador. Resumos. MH080, 1999. 